\title{
Salmonella Enteritidis in the Eggs of Japanese Quails (Coturnix coturnix japonica - Temminck \& Schlegel, 1849) Fed Diets With Different Calcium and Phosphorus Levels
}

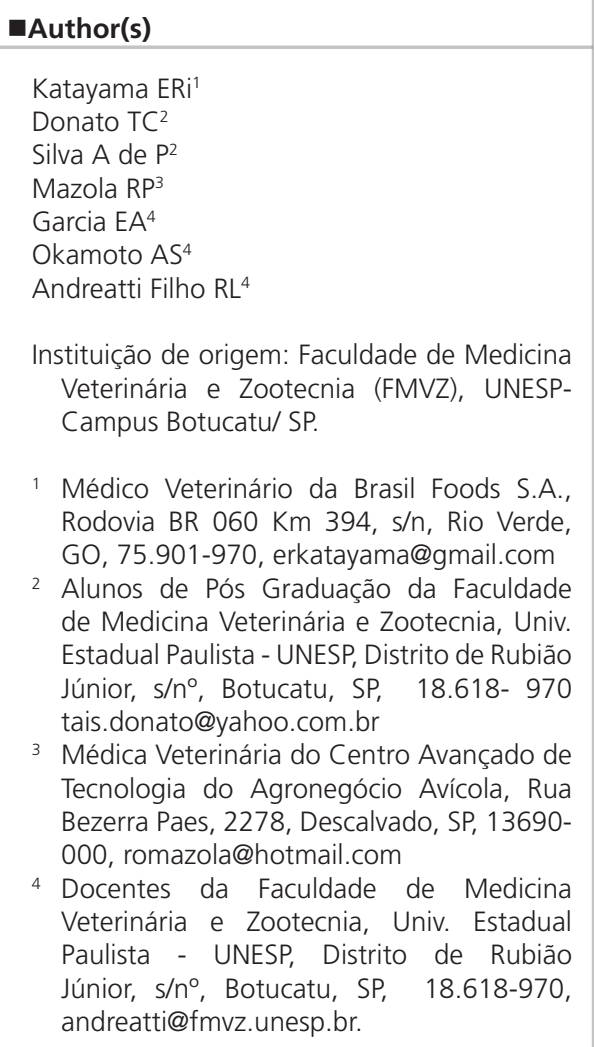

Mail Adress

Corresponding author e-mail address Taís Cremasco Donato

Hospital Veterinário, s/n , Laboratório de Ornitopatologia - Prédio da Patologia Distrito de Rubião Junior - Botucatu - São Paulo, Cep: 18618-970.

Telefones: (14) 3880-2073 ou (14) 81423063

Email: tais.donato@yahoo.com.br ou erkatayama@gmail.com

\section{nKeywords}

Calcium, quail production, Coturnix japonica, phosphorus, salmonellosis.

\section{ABSTRACT}

Several studies point out that eggs are the main cause of human salmonellosis, particularly when poorly processed or eaten raw. In addition of causing public health problems, the presence of Salmonella hinders international food trade, and therefore, it is a health barrier. There are several predisposing factors for the contamination of internal egg content by Salmonella spp, including eggshell quality, which is related to dietary calcium (Ca) and phosphorus (P) levels. In this study, eggs from Japanese quails fed diets containing two different Ca $(2.0$ or $3.5 \%)$ or $\mathrm{P}(0.25$ or $0.45 \%)$ levels were evaluated. Three production phases were used in the experiment: starter, intermediate, and final. The presence of Salmonella Enteriditis in the eggshell and internal content in in the periods of $0,24,96$, and 168 hours after the experimental contamination of the eggs by immersion in broth containing Salmonella Enteriditis. The bacterium was detected in decreasing numbers in the eggshell of eggs from all treatments and during all storage periods. No significant bacterial numbers were found in the internal egg content in none of the treatments during none of the production phases. Therefore, the evaluated $\mathrm{Ca}$ and $\mathrm{P}$ levels in the diet of Japanese quails did not result in higher or lower public health risk relative to the presence of Salmonella Enteritidis in the internal egg content.

\section{INTRODUCTION}

One of the biggest challenges in industrial poultry production in the last few years is salmonellosis, as they cause productivity losses and mortality increases, in addition of posing a risk to public health, as poultry products for human consumption may be contaminated. Poultry products are often implicated in foodborne diseases in humans, which suggest that such products may be sources of infection (Santos \& Turnes, 2005).

Salmonellosis is an important global zoonosis. It is endemic, has high morbidity, and it is difficult to control and to eradicate (Germano \& Germano, 2000). Humans are usually infected by consuming contaminated foods, particularly by Salmonella enterica subspecies enterica serotype Enteritidis (SE) (Andreatti Filho, 2007). The main sources of human infection by Salmonella spp are raw eggs and underprocessed foods (Gast \& Beard, 1992; Humphrey, 1994).

Eggs may be contaminated in the ovary, during its passage through the oviduct, or after lay (Humphrey, 1994). Some egg structures, such as cuticle, eggshell, internal membranes, and albumen may protect the yolk from microbiological contamination (Tranter \& Board, 1982). Moreover, eggshell quality, the natural cooling of the egg after lay, air humidity, hygiene conditions, eggshell surface treatments, and egg 
storage time and temperature influence the entrance of bacteria from the egg surface to the inside (Sauter \& Petersen, 1974; Padron, 1990; Schoeni et al., 1995).

Dietary calcium ( $\mathrm{Ca}$ ) and phosphorus $(\mathrm{P})$ levels are among the main factors affecting eggshell quality (Oliveira, 2004). However, there is little information in literature on Japanese quail nutrition. The NRC (1994), for instance, presents only one nutritional requirement table for the entire egg-production phase, suggesting a Ca requirement of $2.5 \%$ for Japanese quails in lay.

Masukawa et al. (1996) fed Japanese quails diets containing different Ca levels (2.0 to $3.5 \%$ ), but did not find any effects on egg specific gravity, eggshell percentage or thickness. On the other hand, Raju et al. (1992) carried out an experiment with four Ca levels, ranging between 2.0 and $3.5 \%$ and found that eggshell thickness was significantly affected by $\mathrm{Ca}$ levels. Pedroso et al. (1999) evaluated different dietary $\mathrm{Ca}(2.5,3.0$, and $3.5 \%)$ and $\mathrm{P}(0.25,0.45,0.65$, and $0.85 \%$ ) levels for quails in lay and recommended levels of $0.45 \% \mathrm{P}$ and $3.5 \% \mathrm{Ca}$ to improve egg specific gravity.

This study aimed at detecting the possible presence of Salmonella enterica subspecies enterica serotype Enteritidis (SE) in experimentally-contaminated eggs of Japanese quails fed diets containing different $\mathrm{Ca}$ ( 2.0 or $3.5 \%)$ and $\mathrm{P}(0.25$ or $0.45 \%)$ levels during all production phases.

\section{MATERIALS AND METHODS}

Birds were housed in cages in poultry house in Edgárdia experimental farm (UNESP, Botucatu, São Paulo). The experiment was divided in three production phases of 28 days each: initial phase, from seven to 22 weeks of age; intermediate phase, from 28 to 38 weeks; and final phase, from 39 to 54 week. At the end of each production phase, eggs were collected from 240 Japanese quails (Coturnix coturnix japonica) for a period of less than 24 hours after lay.

During the entire experimental period, birds were submitted to the same feeding management, with water and feed supplied ad libitum. Feed was supplied twice daily. The experimental diets were based on corn and soybean meal, and were formulated to supply the nutritional requirements according to NRC (1994). The diets contained equal nutrient levels, except for $\mathrm{Ca}$ and $\mathrm{P}$.

Birds $(n=240)$ were distributed according to a randomized block design into four treatments with three replicates of 20 birds each: treatment 1 (T1)- birds fed $2.0 \% \mathrm{Ca}$ and $0.25 \%$ P; treatment 2 (T2)- birds fed
2.0\% Ca and 0.45\% P a; treatment 3 (T3)- birds fed $3.5 \% \mathrm{Ca}$ and $0.25 \% \mathrm{P}$; treatment 4 (T4)- birds fed $3.5 \% \mathrm{Ca}$ and $0.45 \% \mathrm{P}$.

In total, 120 eggs were collected at the end of each production phase, out of which 96 were used for Salmonella Enteritidis detection after experimental contamination and 24 for evaluating possible previous contamination.

A culture of Salmonella enterica subspecies enterica serotype Enteritidis (SE), mutant resistant to nalidixic acid (Nal) and rifampin (Rif) and isolated from the liver of broiler breeders, was prepared in successive cultures in brilliant-green agar (BGA) containing nalidixic acid $(100 \mathrm{~g} / \mathrm{mL}$ medium) and rifampin $(100 \mathrm{~g} / \mathrm{mL}$ medium).

The obtained culture was plated on BGA with $\mathrm{Nal}$ and Rif, and the pure colonies were collected and diluted in sodium chloride solution $(\mathrm{NaCl})$ at $0.85 \%$ until McFarland turbidity standard 01 . This was subsequently confirmed in a spectrophotometer at $550 \mathrm{~nm}$ and reached 0.250 absorbance, corresponding to $10^{8}$ colony-forming units per $\mathrm{mL}(\mathrm{CFU} / \mathrm{mL})$. At the time of use, it was diluted 100x in buffered peptone water (BPW). The number of CFU/mL was determined by decimal dilutions in BPW, which were then plated on BGA.

Eggs were immersed for three minutes in the SE culture, containing $10^{6} \mathrm{CFU} / \mathrm{mL}$, and stored in plastic egg boxes at the Ornithopathology Laboratory of the School of Veterinary Medicine and Animal Science (UNESP, Botucatu, SP) at environmental temperature $\left(25^{\circ} \mathrm{C}\right)$. After $0,24,96$, and 168 hours of immersion, SE was counted in the eggshell and internal content of a pool of two eggs per replicate.

Eggshell contamination was evaluated by placing the egg pool in plastic bags containing $15 \mathrm{~mL}$ BPW for three minutes, and then serial decimal dilutions of this solution were plated in duplicate in BGA containing $\mathrm{Nal}$ and Rif. Eggs were then immersed in a $70 \%$ ethanol solution for five minutes. After drying, eggs were aseptically broken, and their internal content mas mixed in $30 \mathrm{~mL} \mathrm{BPW}$, and serially diluted as described above. Due to the smaller volume of quail eggs relative to chicken eggs and to the lower amount of eggs tested, the BPW volume used by Barros et al. (2001) was reduced.

All the procedures to which birds were submitted in the present experiment followed the animal experimentation norms and ethical principles established by the Animal Experimentation Ethics Committee of FMVZ/UNESP, which approved this experiment under Protocol n. 68/2009-CEEA) as of April 28, 2009. 
Katayama ERi, Donato TC, Silva A de P, Mazola RP, Garcia EA, Okamoto AS,

Andreatti Filho RL

\section{RESULTS AND DISCUSSION}

SE counts found in the eggshells and internal content of the eggs of the experimental quails during the different production phases are shown in Tables 1 and 2 .

Table 1 - Detection of Salmonella Enteritidis (CFU/mL) in the eggshells of experimentally-contaminated quail eggs after $0,24,96$, and 168 hours, according to production phase.

Initial production phase

\begin{tabular}{|c|c|c|c|c|}
\hline Treatment* & \multicolumn{4}{|c|}{ Storage periods } \\
\hline & $\mathrm{Oh}$ & $24 \mathrm{~h}$ & $96 \mathrm{~h}$ & $168 \mathrm{~h}$ \\
\hline T1 & $1.4 \times 10^{3} \mathrm{Aa}$ & $4.8 \times 10^{2} \mathrm{Aa}$ & $1.2 \times 10^{3} \mathrm{Aa}$ & $5.3 \times 10^{1} \mathrm{Aa}$ \\
\hline $\mathrm{T} 2$ & $1.2 \times 10^{3} \mathrm{Aa}$ & $2.0 \times 10^{2} \mathrm{Aa}$ & $6.0 \times 10^{1} \mathrm{Aa}$ & $5.9 \times 10^{2} \mathrm{Aa}$ \\
\hline T3 & $1.0 \times 10^{3} \mathrm{Aa}$ & $1.3 \times 10^{2} \mathrm{Ab}$ & $3.7 \times 10^{1} \mathrm{Ab}$ & $2.0 \times 10^{1} \mathrm{Ab}$ \\
\hline T4 & $9.7 \times 10^{2} \mathrm{Aa}$ & $1.3 \times 10^{2} \mathrm{Ab}$ & $1.1 \times 10^{2} \mathrm{Ab}$ & $5.7 \times 10^{1} \mathrm{Ab}$ \\
\hline \multicolumn{5}{|c|}{ Intermediate production phase } \\
\hline T1 & $2.6 \times 10^{3} \mathrm{Aa}$ & $3.8 \times 10^{2} \mathrm{Aa}$ & $1.2 \times 10^{4} \mathrm{Aa}$ & $1.0 \times 10^{1} \mathrm{Aa}$ \\
\hline $\mathrm{T} 2$ & $1.7 \times 10^{3} \mathrm{Aa}$ & $8.1 \times 10^{2} \mathrm{Aa}$ & $8.7 \times 10^{2} \mathrm{Aa}$ & $4.4 \times 10^{2} \mathrm{Ba}$ \\
\hline T3 & $3.7 \times 10^{3} \mathrm{Aa}$ & $1.5 \times 10^{2} \mathrm{Aa}$ & $1.3 \times 10^{2} \mathrm{Aa}$ & $1.2 \times 10^{2} \mathrm{Aba}$ \\
\hline T4 & $5.9 \times 10^{3} \mathrm{Aa}$ & $2.5 \times 10^{2} \mathrm{Ab}$ & $1.6 \times 10^{2} \mathrm{Ab}$ & $7.5 \times 10^{1} \mathrm{ABb}$ \\
\hline
\end{tabular}

Final production phase

\begin{tabular}{ccccc}
\hline T1 & $1.8 \times 10^{3} \mathrm{Aa}$ & $6.9 \times 10^{3} \mathrm{Aa}$ & $1.6 \times 10^{2} \mathrm{Aa}$ & $4.0 \times 10^{1} \mathrm{Ab}$ \\
\hline $\mathrm{T} 2$ & $1.6 \times 10^{3} \mathrm{Aa}$ & $2.9 \times 10^{2} \mathrm{Aa}$ & $1.0 \times 10^{4} \mathrm{Aa}$ & $9.3 \times 10^{1} \mathrm{Aa}$ \\
\hline $\mathrm{T} 3$ & $4.1 \times 10^{3} \mathrm{Aa}$ & $2.1 \times 10^{2} \mathrm{Aa}$ & $2.1 \times 10^{2} \mathrm{Aa}$ & $1.3 \times 10^{2} \mathrm{Aa}$ \\
\hline $\mathrm{T} 4$ & $2.9 \times 10^{3} \mathrm{Aa}$ & $2.8 \times 102 \mathrm{Aab}$ & $4.4 \times 10^{2} \mathrm{Aab}$ & $7.0 \times 10^{1} \mathrm{Ab}$ \\
\hline
\end{tabular}

*T1 (Ca 2.0\%; P 0.25\%); T2 (Ca 2.0\%; P 0.45\%); T3 (Ca 3.5\%; P 0.25\%); T4 (Ca $3.5 \% ; P$ P $0.45 \%)$

Different capital letter in the same column and different small letters in the same row indicate significant differences among treatments and storage periods, respectively, by the test of Tukey $(p \leq 0.05)$. Production phases were not compared.
Salmonella Enteritidis in the Eggs of Japanese Quails (Coturnix coturnix japonica - Temminck \& Schlegel, 1849) Fed Diets With Different Calcium and Phosphorus Levels

Table 2 - Detection of Salmonella Enteritidis (CFU/mL) in the internal egg content of experimentally-contaminated quail eggs after $0,24,96$, and 168 hours, according to production phase.

Initial production phase

\begin{tabular}{ccccc}
\hline Treatment* & \multicolumn{3}{c}{ Storage periods } \\
& Oh & $24 h$ & $96 h$ & $168 h$ \\
\cline { 2 - 4 } T1 & OAa & OAa & OAa & OAa \\
T2 & OAa & OAa & OAa & $3.0 \times 10^{1} \mathrm{Aa}$ \\
T3 & OAa & OAa & OAa & OAa \\
T4 & OAa & OAa & OAa & OAa \\
\hline
\end{tabular}

Intermediate production phase

\begin{tabular}{ccccc}
\hline T1 & OAa & OAa & $7.5 \times 10^{2} \mathrm{Aa}$ & OAa \\
\hline T2 & OAa & OAa & OAa & $9.3 \times 10^{1} \mathrm{Aa}$ \\
\hline T3 & OAa & OAa & OAa & OAa \\
\hline T4 & OAa & OAa & OAa & OAa \\
\hline
\end{tabular}

Final production phase

\begin{tabular}{ccccc}
\hline T1 & OAa & OAa & OAa & OAa \\
\hline T2 & OAa & OAa & $8.3 \times 10^{1} \mathrm{Aa}$ & OAa \\
\hline T3 & OAa & OAa & $1.0 \times 10^{1} \mathrm{Aa}$ & $0 \mathrm{Aa}$ \\
\hline $\mathrm{T} 4$ & OAa & OAa & OAa & OAa \\
\hline
\end{tabular}

*T1 (Ca 2.0\%; P 0.25\%); T2 (Ca 2.0\%; P 0.45\%); T3 (Ca 3.5\%; P 0.25\%); T4 (Ca $3.5 \% ; P$ P $0.45 \%)$.

Different capital letter in the same column and different small letters in the same row indicate significant differences among treatments and storage periods, respectively, by the test of Tukey $(P \leq 0.05)$. Production phases were not compared.

The presence of SE was detected in the eggshells from all treatments and at all storage periods, in agreement with the results obtained in layers, with significant SE counts during all analyzed periods (Barros et al., 2001; Humphrey et al., 1991; Gast \& Beard, 1992; Schoeni et al., 1995). Eggshell SE counts decreased with time of storage in eggs from all treatment and production 
Katayama ERi, Donato TC, Silva A de P, Mazola RP, Garcia EA, Okamoto AS, Andreatti Filho RL
Salmonella Enteritidis in the Eggs of Japanese Quails (Coturnix coturnix japonica - Temminck \& Schlegel, 1849) Fed Diets With Different Calcium and Phosphorus Levels phases evaluated. There were no significant differences in eggshell SE counts among treatments within a same production phase because of the wide range of CFU/ $\mathrm{mL}$ among the three replicates of a same treatment. For the same reason, the decrease in SE counts during storage was not always significantly different among the evaluated periods.

No significant SE counts were detected inside the eggs (albumen and yolk) in none of the three production phases, which is consistent with the results obtained by Barros et al. (2001) in eggs of commercial layers. Most of the time, SE was not detected inside the egg. When this happened, SE was detected in only one of the replicates. Where SE was detected inside the egg, the replicate usually also presented high SE counts in the eggshell, which may be due to eggshell defects (e.g., cracks) and/or the presence of organic matter attached to the shell. In the initial production phase, SE was detected in treatment T2 (Ca: 2.0\%; P: $0.45 \%) 168$ hours after storage. During the intermediate phase, T1 and T2 presented SE 96 and 168 hours after storage. In the final production phase, SE was detected in treatments T2 and T3 (Ca: 2.0\%; P: $0.45 \%$ ) after 96 hours of storage.

Oliveira \& Silva (2000) found significant SE contamination of the yolk of commercial chicken eggs derived from the eggshell 24 hours after experimental contamination. Antibacterial found in the albumen, such as antibacterial enzymes and iron ion deficiency, may explain the reduced counts and even the absence of SE in the internal egg content, as it was entirely (albumen and yolk) used.

\section{ACKNOWLEDGEMENTS}

The authors thank Conselho Nacional de Desenvolvimento Científico e Tecnológico for funding this project.

\section{CONCLUSIONS}

Eggs produced by Japanese quails fed diets with the evaluated $\mathrm{Ca}$ and $\mathrm{P}$ levels did not present eggshell changes allowing any significant contamination of their internal content by Salmonella Enteritidis. However, eggs from birds fed the highest calcium and phosphorus levels ( $\mathrm{Ca} 3.5 \%$; $\mathrm{P}$ 0.45\%) did not present any contamination of their internal content by Salmonella Enteritidis in none of the evaluated storage times.

\section{REFERENCES}

Andreatti Filho, RL. Paratifo aviário. In: Andreatti Filho, RL. Saúde Aviária e Doenças. São Paulo: ROCA; 2007. p.96-106.

Barros MR, Andreatti Filho, RL, Lima ET, Sampaio HM, Crocci AJ. Survival of Salmonella enteritidis in eggs artificially contaminated, after disinfection and stored at different temperatures. Revista Brasileira Ciência Avícola 2001;3(3):219-23

Gast RK, Beard CW. Detection and enumeration of Salmonella Enteritidis in fresh and stored eggs laid by experimentally infected hens. Journal of Food Protection 1992;55:152-6

Germano PML, Germano MIS. Higiene e vigilância sanitária de alimentos São Paulo: Varela; 2000. p. 629.

Humphrey TJ, Whitehead AH, Gawler AHL, Henley A, Rowe B. Numbers of Salmonella Enteritidis in the contents of naturally contaminated hens' eggs. Epidemiology Infection 1991;106:489-96.

Humphrey TJ. Contamination of eggshell and contents with Salmonella Enteritidis: a review. International Journal of Food Microbiology 1994;21:31-40.

Masukawa Y, Moraes VMB, Ariki J, Pedroso AA, Salvador D. Efeitos dos níveis de cálcio sobre o desempenho produtivo e qualidade dos ovos de codornas japonesas (Coturnix coturnix japonica). Anais da Conferência Apinco de Ciência e Tecnologia Avícolas; 1996; Curitiba, Paraná. Brasil. p. 35.

National Research Council. Nutrient requeriments of poultry. $9^{\text {th }}$ ed. Washington: National Academic Press; 1994. p.155.

Oliveira DD, Silva EN. Salmonela em ovos comerciais: ocorrência, condições de armazenamento e desinfecção da casca. Arquivo Brasileiro Medicina Veterinária e Zootecnia 2000;52:655-61.

Oliveira EG, Almeida MIM. Algumas informações sobre nutrição de codornas para corte. Anais do Simpósio Internacional de coturnicultura; 2004; Lavras, Minas Gerais. Brasil. p. 53-64.

Padron MN. Salmonella Typhimurium penetration through the eggshell of hatching eggs. Avian Disease 1990;34:463-5.

Pedroso A, Moraes VMB, Ariki J, Kronka SN. Níveis de cálcio e fósforo na ração sobre o desempenho e qualidade dos ovos de codornas japonesas. ARS Veterinária 1999;15(2):135-39.

Raju MVLN, Rao PV, Reddy VR. Effect of dietary calcium and inorganic phosphorus on the performance of laying coturnix quail. Indian Journal of Animal Science; 1992;62(11):1072-76.

Santos JRG, Turnes CG. Probióticos em avicultura. Ciência Rural 2005;35(3):741-47

Sauter EA, Petersen, CF. The effect of egg shell quality on penetration by various Salmonellae. Poultry Science ;1974;53:2159-62.

Schoeni JL, Glass KA, Mcdermott JL, Wong ACL. Growth and penetration of Salmonella Enteritidis, Salmonella Heidelberg and Salmonella Typhimiurium in eggs. International Journal of Food Microbiology 1995;24:385-96.

Tranter HS, Board RG. The antimicrobial defense of avian eggs: biological perspective and chemical basis. Journal of Applied Biochemistry $1982 ; 4: 295-338$. 